\title{
Ebonics: The Debate Which Never Happened
}

\author{
Barbara Birch \\ Westwood College of Technology
}

The thesis of this paper is that no substantive and impartial debate about the pedagogical value of using Ebonics in the classroom could be held in the United States media because America's prescriptive attitude towards Ebonics does not allow fair and objective consideration of the issue. In presenting this theme I will discuss language ideologies in general and prescription in particular as a common attitude towards language. Prescription with respect to Ebonics usually takes the form of language prejudice. I will conclude with an introduction to one area of language planning, status planning, in which language planners try to improve the status of a dialect or language by selecting a goal, planning the necessary research, and devising a marketing or diffusion plan.

In December, 1996, the Oakland School Board announced a plan to use Ebonics in the classroom, and their decision evoked outrage in the media for four months. This paper is not 
in support or in opposition to the school board's plan, nor does it debate the pros and cons of any concrete proposal. The point of this paper is not to argue the status of Ebonics as a separate language, a dialect of English, or a variety of English. Instead my purpose is to discuss the undeniable fact that the plan was never discussed reasonably and impartially in the media for four months because kneejerk negative attitudes towards Ebonics, a form of linguistic prejudice, made a true debate about the issue impossible.

Some terms and definitions are in order. Standard American English (SAE) is the most commonly acceptable way of speaking or writing American English which may not follow all grammar rules in the books but is intelligible to most Americans. It has some regional dialect variation from north to south and from east to west, but is mutually intelligible because of a common core of usage. Ebonics is a way of speaking mainly available to African-Americans, though people of other ethnicities speak it. It has certain lexical, phonological, and grammatical features different from SAE, but its use is highly individualistic. For some speakers it is a native dialect or language; for others it is merely a slight, socially context-dependent variation from SAE. Any types of American speech that diverge substantially from SAE are called non-standard; they include Ebonics, Cajun, Pennsylvania Dutch, and some rural and urban ways of speaking.

According to Pennycook, Phillipson, and Wiley, two major ideologies of language are operant in the world today.

\section{Ideologies of Language}

\section{Colonial/Imperialistic}

People do not have language rights.

One language/dialect is better than others; it should be used exclusively.

\section{Ecology of Language}

People have language rights.

Languages/dialects have equal status, but different functions. 
Monolingualism is considered the norm; others should learn the dominant language.

Laissez faire or "survival of the fittest" is the prevailing attitude toward minority dialects and languages.

Multilingualism is a "problem."
Multilingualism is the norm for societies and individuals.

Protection and maintenance of minority languages and dialects are necessary.

Multilingualism is

a "resource."

We see signs of both of these ideologies in the United States today, but policy-shapers, decision-makers, voters, and the media generally fall into the colonialist/imperialist camp. The colonialist/imperialist view towards Ebonics can be summarized: African Americans do not have the right to speak the way that they want to because Standard American English is better than Ebonics. Speakers of Ebonics should learn Standard American English because Ebonics is of no value to our society and culture. It survives in spite of diligent efforts to eradicate it. Ebonics is a problem for African Americans to overcome if they are to be able to benefit from social and economic opportunities in our society.

In contrast, the ecological view is that African Americans have the right to use Ebonics if they want to because it is equal in status to SAE. Although SAE and Ebonics are equal in status, they may have different functions in society. For example, SAE is acceptable in business, education, and government, and Ebonics is at present acceptable in homes, neighborhoods, and churches. In recent years there are some overlaps in function in areas of sports, movies, and television where both are acceptable. Ebonics has a value because it is normal for people to have multiple ways of speaking. Ebonics is a resource for our culture and a resource for the individual who speaks it; therefore it should be maintained. 
To understand the negative public reaction to the Oakland School Board plan to use Ebonics in the classroom to enhance student learning, however, we need to tease apart language attitudes in more detail. We zero in on the prescriptive attitude that SAE is better than nonstandard varieties of English and that therefore everyone should speak it. We can, in fact, separate out a continuum of language attitudes along an axis of equality VS prejudice (See chart on page 5.). The left column, "equality," generally reflects the descriptivist posture of most linguists, who attempt to root out their own prejudices towards the diverse ways that people speak in order to study 'language' more objectively. After adopting this descriptivist stance linguists have determined that all languages (English, German, French, Chinese, etc.) are in theory effective and valid for all functions (education, government, business, home, neighborhoods, media). They extend this view to all languages without exception: Ebonics, Cajun, and Pennsylvania Dutch could be effective and valid language choices to fulfill any language function.

The most introductory of linguistics textbooks contain the observation that the language, dialect, or variety that people speak correlates with a number of social factors, such as regional origin, nationality, ethnicity, gender, education level, social class, or mobility. Ways of speaking do not correlate well with intelligence or morality. This, of course, merely confirms what we observe anecdotally: intelligent and highly moral people can use double negatives and unintelligent and unscrupulous people can speak "perfect" English. In spite of this there is a pernicious view that people who speak "ungrammatically" are somehow deficient, stupid, bad, even criminal. My local newspaper, for example, printed an editorial from a reader who felt that people who couldn't spell correctly or use the right past participle were showing the same slovenly thinking as those who commit hate crimes or child abuse.

One of the first lessons a student of linguistics learns is that our norms of language, our attitudes towards properness in language, and our expectations about the ways that people should speak are not inherent but rather are reflections of long 


\section{Ethnic Studies Review Volume 22}

and deeply embedded ethnic, social, economic and gender privilege. In other words SAE is the standard in this country because it was and has been and is traditionally the speech of the white upper and middle class. This is, of course, a simplified summary of a very complex issue in the field of historical social psychology of language, but it is the case that SAE is not inherently more melodious than a working class Bostonian variant; it is not more logical than Gullah, and it is not more beautiful than Cajun. Our norms, attitudes, and expectations are based merely on perceived privilege: languages and dialects share the same prestige as their speakers do in society. In addition there is gender privilege which operates on a smaller scale; we see the growth industry of workshops designed to teach businesswomen to speak more assertively and with more power, even to the point of lowering their voice pitch, as if that were the only correct way of getting a point across.

\section{Attitudes towards minority varieties, dialects, or languages}

$\begin{array}{lll}\text { equality } & \begin{array}{l}\text { pragmatic } \\ \text { prescriptivism }\end{array} & \begin{array}{l}\text { language } \\ \text { prejudice }\end{array} \\ \text { All dialects are } & \text { All dialects } & \text { SAE is correct; } \\ \text { effective and } & \text { are effective } & \text { others are } \\ \text { valid for all } & \text { and valid for } & \text { ungrammatical } \\ \text { communicative } & \text { many } & \text { and need } \\ \text { functions. } & \begin{array}{l}\text { communicative } \\ \text { functions, }\end{array} & \begin{array}{l}\text { fixing. } \\ \text { but, like it or not, } \\ \text { one is accepted }\end{array} \\ & \begin{array}{l}\text { They may be } \\ \text { called "slovenly } \\ \text { thinking," "lazy }\end{array} \\ & \begin{array}{l}\text { business, } \\ \text { government, }\end{array} & \text { speech," } \\ & \text { "deficient," or } \\ & \text { and education. } & \end{array}$


Birch-Ebonics

\begin{tabular}{|c|c|c|}
\hline $\begin{array}{l}\text { Intelligence } \\
\text { and morality } \\
\text { are not } \\
\text { correlated } \\
\text { with dialect/ } \\
\text { language. }\end{array}$ & $\begin{array}{l}\text { Intelligence and } \\
\text { morality are not } \\
\text { correlated with } \\
\text { dialect/language. }\end{array}$ & $\begin{array}{l}\text { People who don't } \\
\text { speak properly and } \\
\text { are stupid and } \\
\text { bad. They may } \\
\text { be called } \\
\text { "sloppy thinkers," } \\
\text { or "lazy } \\
\text { speakers." }\end{array}$ \\
\hline $\begin{array}{l}\text { Our norms of } \\
\text { speech and } \\
\text { writing are due } \\
\text { to long } \\
\text { ethnic, social, } \\
\text { economic, and } \\
\text { gender } \\
\text { privilege. }\end{array}$ & $\begin{array}{l}\text { Our norms of } \\
\text { speech and } \\
\text { and writing } \\
\text { reflect ethnic, } \\
\text { social, economic, } \\
\text { or gender } \\
\text { privilege. }\end{array}$ & $\begin{array}{l}\text { Our norms of } \\
\text { proper speech } \\
\text { and writing are } \\
\text { enshrined by } \\
\text { tradition } \\
\text { and grammar } \\
\text { books. } \\
\text { No privilege is } \\
\text { involved } \\
\text { because all can } \\
\text { learn. }\end{array}$ \\
\hline
\end{tabular}

The other extreme, that of language prejudice, seems to reflect a common point of view that there is one proper way of speaking and writing and that those who don't speak it have something wrong with them. The "prescription" to heal the deficiency is to learn proper English grammar rules and writing. Furthermore, there are implicit and explicit moral judgments made about those whose grammar is nonstandard. Overt prejudice against nonstandard speakers is considered praiseworthy at a time when other types of overt prejudice have diminished or have at least become more covert. Nonstandard dialect speakers (not just Ebonics speakers) are viewed as stupid, ignorant, lazy, sloppy, or bad. People who hold prejudicial attitudes believe that proper English is somehow historically better, more logical, more refined, more expressive, and so on, possibly because it has grammar books that authenticate it. The history of grammar books and instruction is beyond the scope of this paper, but suffice it to say that grammar book writ- 


\section{Ethnic Studies Review Volume 22}

ers and publishers often capitalize on our linguistic insecurities to make a buck.

In the center column, we find what might be called pragmatic prescriptivism, a middle-of-the-road view that incorporates the sociolinguistic truths revealed by linguists with the pragmatism of operating within a culture and society in which $S A E$ is the dominant language. In pragmatic prescriptivism teachers and others might believe that SAE and Ebonics are equally valid and appropriate but that they have different functions. I am grateful to my colleague, Dr. James Walton, for a useful analogy. We wear both jeans and business suits on different occasions. One is not more valued than the other; they are just different. We expect to wear jeans appropriately sometimes and business suits appropriately at other times. The same can be true of speech. We can appreciate different varieties of speech equally but recognize that they are appropriate in different settings and situations. The result for pedagogy of the attitudes of equality, pragmatic prescriptivism, and prejudice are shown in this table:

\section{Teacher Attitudes towards Nonstandard Dialects}

\begin{tabular}{|c|c|c|}
\hline equality & $\begin{array}{l}\text { pragmatic } \\
\text { prescriptivism }\end{array}$ & $\begin{array}{l}\text { language } \\
\text { prejudice }\end{array}$ \\
\hline $\begin{array}{l}\text { Teachers should } \\
\text { internalize } \\
\text { socio- } \\
\text { linguistic } \\
\text { truths. } \\
\text { Learning can } \\
\text { take place in } \\
\text { any dialect. }\end{array}$ & $\begin{array}{l}\text { It is the teacher's role } \\
\text { to respect students' } \\
\text { home dialect } \\
\text { and internalize } \\
\text { sociolinguistic } \\
\text { truths. }\end{array}$ & $\begin{array}{l}\text { It is the teacher's } \\
\text { role to } \\
\text { eradicate errors } \\
\text { from their } \\
\text { students' speech } \\
\text { and writing. }\end{array}$ \\
\hline
\end{tabular}




\begin{tabular}{|c|c|c|}
\hline $\begin{array}{l}\text { People should } \\
\text { be able to speak } \\
\text { and write the } \\
\text { way they want } \\
\text { to, as long } \\
\text { as other } \\
\text { people can } \\
\text { understand. }\end{array}$ & $\begin{array}{l}\text { People should } \\
\text { be able to } \\
\text { speak and } \\
\text { write the way } \\
\text { they want to, } \\
\text { but they } \\
\text { should be } \\
\text { encouraged } \\
\text { to learn SAE } \\
\text { for some } \\
\text { functions. }\end{array}$ & $\begin{array}{l}\text { People should } \\
\text { speak and } \\
\text { write SAE always. } \\
\text { Attempts } \\
\text { to change any } \\
\text { standards are } \\
\text { "dumbing down" } \\
\text { or even } \\
\text { "racist" because } \\
\text { they imply } \\
\text { that some } \\
\text { cannot learn. }\end{array}$ \\
\hline $\begin{array}{l}\text { Use of a home } \\
\text { dialect in school } \\
\text { is allowed. }\end{array}$ & $\begin{array}{l}\text { Use of the } \\
\text { students'dialect } \\
\text { in school in order } \\
\text { to promote } \\
\text { content area and } \\
\text { SAE learning } \\
\text { is allowed. }\end{array}$ & $\begin{array}{l}\text { Use of the } \\
\text { students' } \\
\text { dialect is } \\
\text { prohibited. } \\
\text { It is "dumbing } \\
\text { down," "catering } \\
\text { to," or "racist." }\end{array}$ \\
\hline
\end{tabular}

The Oakland School Board's plan fell, I believe, into the pragmatic prescriptivism view, but the reaction of the general public, as reported in the media, was characterized by language prejudice. The premise of this paper is that in order for there to be a true debate about the merits of using Ebonics in the classroom, the opinion of the general public, policy makers, and decision-makers has to shift from prejudice towards pragmatic prescriptivism. It is only within that domain that goals and objectives can be set, plans can be made and carried out, and learning results quantified.

Although changes in attitudes towards language and dialect are extremely difficult to accomplish, they can be attempted through language status planning. Language status planning is a field devoted to increasing the number of functions that a language or dialect has in a society by making it more acceptable in different settings, such as school, government, literature, and so on. There have been status planning 


\section{Ethnic Studies Review Volume 22}

attempts in Louisiana, with French and Cajun, that have met with only mixed success (Valdman 97). There has been more successful status planning in Canada with French and Native American languages. These status-planning efforts have given us some ideas of what works and what doesn't.

Status planning works best as a grassroots effort by the speakers of the language, aided by experts, academicians, and authorities (Cooper 99-121). If speakers value their own language and culture and experts and authorities support it, they will make it valued by others. To be more specific, to improve the status of Ebonics the speakers themselves must first see their own ways of speaking as resources for them and not as problems to be overcome. An increase in the status of Ebonics will not come from outside this population. However, the truth is that at present many African Americans do not see Ebonics as a separate variety of English; their use of it is unconscious. If they are aware of it, many African Americans do not value Ebonics because they themselves have internalized societal language prejudice against Ebonics.

Although many linguists value Ebonics, some prominent African-Americans do not. In the reaction against the Oakland School Board's plan, people like Bill Cosby and Maya Angelou gave legitimacy to language prejudice. Because they opposed the plan, others could openly oppose it without the danger of being perceived as racist or prejudiced. For Ebonics speakers to raise the status of their way of speaking, they must become aware of it as a valued variety; they must throw off internalized prejudice, and prominent African Americans must support status-planning efforts, as Toni Morrison did.

A status plan must have a goal, a research plan, and a method of diffusion. The goal for the grassroots movement supported by experts might range from a simple awareness of the history, functions, and value of Ebonics as a resource among African Americans to a more challenging goal of acceptance of Ebonics by the general public as a legitimate mode of expression with a function to play within education, business, and government. Depending on which goal is selected, the research plan might include surveys of language use in the 
community of speakers, e.g. the number of bidialectal and monodialectal speakers of Ebonics in rural and urban areas of the north, south, east, and west, the current functions it has in the home, neighborhood, media, church, school, workplace, academe, and the awareness and attitudes of African Americans and other Americans towards it. There has already been funding allocated by the federal government for research on the relationship of Ebonics and African American students' success in learning to read and write in SAE to be carried out in both Oakland and Philadelphia (Rickford 98).

Further research might include studies of the best ways to influence public opinion about language from the bottom up or from the top down. Rickford discusses the media in his attempts to convey the point of view of linguists to the public. $\mathrm{He}$ finds that newspapers are unsatisfactory because they actually prevent views opposed to mainstream attitudes from reaching people but that radio is more satisfactory. His view is ". . . the message has to be repeated...anew for each generation and each different audience type, and preferably in simple, direct and arresting language which the public can understand and appreciate" (98).

After the goal has been chosen and the research carried out, a diffusion plan must be made and put into action. The logical place to begin from the bottom up is with a grassroots revaluing of Ebonics which would extend out from radio and television, internet, the African American media and churches, which would influence the masses as well as prominent African Americans who are in a position to influence others. Teacher education is another area where information about Ebonics can be influential. From the top down, language experts and Ebonics scholars should not let up on their efforts to educate our federal and state government and school officials. This is also an area where the National Association of Ethnic Studies could continue to provide some leverage, as does the Linguistic Society of America and the Society for Linguistic Anthropology.

But there are important obstacles to change. First, colonialist/imperialist ideology and language prejudice are 


\section{Ethnic Studies Review Volume 22}

entrenched in our society. People see these as the norm and are unable to entertain other points of view. People who express different points of view, like the Oakland School Board, are shouted down. Linguists like Rickford and others (including myself) received hate mail for expressing such views. That is because language prejudice often thinly masks deep-seated racial prejudices, such as were seen in Web sites which became active during the Ebonics "debate."

However on the plus side the Ebonics issue is an important one for addressing language prejudice and racism in our society, and, handled properly, it can offer opportunities for people to change. That is because although Ebonics is an extremely clear example of language prejudice, it is only one part of a bigger problem. The fact is that everyone is judged by the way that they speak and write, and many people of all social classes and ethnicities face prejudice because of their dialects and accents. Southerners with strong accents are viewed as backwoods racist louts; Jimmy Carter tried to reduce his southern accent for that reason although his speech was very close to "standard." People with northern urban accents are viewed often as stupid street-gang members or members of the Mob. The use of Yiddish-influenced English or Spanishinfluenced English evokes a negative response from some Americans. In short language prejudice is confronted by many, and therefore it could be "exploited" to show the commonality of our experience as English speakers. In a true debate about Ebonics we as a society might become aware of our language prejudices and privileges, which is the first step in changing them.

\section{WORKS CITED}

Cooper, R. Language Planning and Social Change. (Cambridge: Cambridge University Press, 1989), 99-121.

Pennycook, A., Phillipson, R., and Wiley, T., Panel Discussion "Ideological Implications of the Spread of English," Sociopolitical Concerns Academic Session, International 
Teachers of English to Speakers of Other Languages (TESOL) Conference, Seattle, WA, March 18, 1998.

Rickford, J. "The Ebonics Controversy in My Backyard: A Sociolinguist's Experiences and Reflections," printed at http://www-leland.stanford.edu/ rickford/ebonics/ and in Language in Society, 98-99.

Valdman, A. French and Creole in Louisiana. (New York: Plenum Press, 1997), 97.

Walton, J., Departments of English and Ethnic Studies, California State University, Fresno, personal communication. 